\title{
Impact of Transplantation of Cryopreserved and Preincubated with Thymic Multipotent Stromal Cells of Hemopoietic Stem Cells on Lethally Irradiated Mice Survival
}

Реферат: В роботі вивчали виживаність і середню тривалість життя 128 мишей лінії СВА, яким на наступний день після летального опромінення внутрішньовенно вводили 0,5 × $10^{6}$ кріоконсервованих сінгенних клітин кісткового мозку (ККМ) або кріоконсервованих сінгенних клітин фетальної печінки (КФП) 14 діб гестації. У частині експериментів клітини із зазначених джерел після розморожування інкубували in vitro протягом 20 годин у присутності колоній мультипотентних стромальних клітин (МСК) тимуса. Встановлено, що контактна взаємодія з тимусними МСК значно підвищує виживаність мишей у результаті трансплантації гемопоетичних стовбурових клітин (ГСК) і прогеніторів різного ступеня зрілості. Преінкубовані з МСК тимуса ККМ підвищують виживаність опромінених мишей у пізній після опромінення період (через 14-16 тижнів - 13\% тварин, що вижили, при 0\% у контролі). Клітини фетальної печінки, преінкубовані з МСК тимуса, підвищують виживаність мишей у ранній період (через 4 тижні - 40\% при 18\% в контролі) і в 2,4 раза збільшують середню тривалість життя тварин. Результати дослідження можуть бути використані для вдосконалення трансплантатів ГСК і способів їх застосування.

Ключові слова: гемопоетичні стовбурові клітини, кріоконсервування, клітини кісткового мозку, клітини фетальної печінки, мультипотентні стромальні клітини тимуса, міжклітинна контактна взаємодія, $\gamma$-опромінення.

Реферат: В работе изучали выживаемость и среднюю продолжительность жизни 128 мышей линии СВА, которым на следующий день после летального облучения внутривенно вводили $0,5 \times 10^{6}$ криоконсервированных сингенных клеток костного мозга (ККМ) или криоконсервированных сингенных клеток фетальной печени (КФП) 14 суток гестации. В части экспериментов клетки из указанных источников после размораживания инкубировали in vitro в течение 20 ч в присутствии колоний мультипотентных стромальных клеток (МСК) тимуса. Установлено, что контактное взаимодействие с тимусными МСК значительно повышает выживаемость мышей в результате трансплантации гемопоэтических стволовых клеток (ГСК) и прогениторов разной степени зрелости. Преинкубированные с МСК тимуса ККМ повышают выживаемость облученных мышей в поздний после облучения период (через 14-16 недель - 13\% выживших животных при 0\% в контроле). Клетки фетальной печени, преинкубированные с МСК тимуса, повышают выживаемость мышей в ранний период (через 4 недели - 40\% при 18\% в контроле) и в 2,4 раза увеличивают среднюю продолжительность жизни животных. Результаты исследования могут быть использованы для совершенствования трансплантатов ГСК и способов их применения.

Ключевые слова: гемопоэтические стволовые клетки, криоконсервирование, клетки костного мозга, клетки фетальной печени, мультипотентные стромальные клетки тимуса, межклеточное контактное взаимодействие, $\gamma$-облучение.

Abstract: Survival and average life expectancy of 128 CBA mice, intravenously injected the next day after lethal irradiation with $0.5 \times 10^{6}$ cryopreserved syngeneic bone marrow cells (BMCs) or cryopreserved syngeneic cells of fetal liver (FLCs) of 14 days of gestation were studied. In some experiments, the cells were incubated in vitro after thawing for $20 \mathrm{hrs}$ with multipotent stromal cells (MSCs) of thymus. It has been established that the contact interaction with thymic MSCs significantly increases the survival of mice as a result of transplantation of hematopoietic stem cells (HSCs) and progenitors of different degrees of maturity. The use of bone marrow cells preincubated with thymic MSCs enhances the survival of irradiated mice at the late post-irradiation stage (after 14-16 weeks that was $13 \%$ of the survived animals with $0 \%$ in the control). Application of fetal liver cells preincubated with thymic MSCs increases the murine survival rate at the early stage (after 4 weeks it was $40 \%$ with $18 \%$ in the control) and in 2.4 times prolongs the average life expectancy of animals. The results can be used to improve the HSC transplants and methods for their application.

Key words: hematopoietic stem cells, cryopreserved bone marrow cells, fetal liver cells, thymic multipotent stromal cells, cell-to-cell interaction, $\gamma$-irradiation.

ДУ «Інститут генетичної та регенеративної медицини НАМН України», м. Київ, Україна
State Institute of Genetic and Regenerative Medicine National Academy of Medical Sciences of Ukraine, Kyiv, Ukraine
Адреса для кореспонденції:

вул. Вишгородська, 67, м. Київ, Україна 04114; тел.: (+38 044) 468-75-50

електронна пошта: nikolskaya.kiev@gmail.com

Надійшла 10.10.2018

Прийнята до друку 13.05.2019
Address for correspondence:

67, Vyshhorodska str., Kyiv, Ukraine 04114;

tel.: +380 444687550

e-mail: nikolskaya.kiev@gmail.com

Received October, 10, 2018

Accepted May, 13, 2019

(c) 2019 K.I. Nikolska. Published by the Institute for Problems of Cryobiology and Cryomedicine

This is an Open Access article distributed under the terms of the Creative Commons Attribution License (http://creativecommons.org/licenses/by/4.0), which permits unrestricted reuse, distribution, and reproduction in any medium, provided the original work is properly cited. 
Для вивчення активності гемопоетичних стовбурових клітин і прогеніторів при регенерації імунної системи найчастіше використовують індукований летальним опроміненням імунодефіцит. Головним патогенетичним механізмом його розвитку є кістково-мозковий синдром, який виникає в результаті ураження кровотворних і лімфоїдних клітин, чутливих до іонізуючого випромінювання. Одночасно внаслідок дії радіації уражується бар'єрна функція епітелію і формується так званий кишковий синдром. Імунодефіцит швидко поглиблюється дією чинників мікробної агресії слизовими оболонками, яка i призводить до летального результату. Припинення цього патологічного процесу можливо тільки завдяки регенерації імунної системи з відновленням протиінфекційного захисту.

На сьогодні найбільш ефективним підходом для регенерації імунної системи є застосування гемопоетичних стовбуроих клітин (ГСК), із яких формуються всі клітини імунної системи, і мультипотентних стромальних клітин (МСК), що забезпечують регуляторний вплив на ГСК [5, 6]. Мембранна спорідненість між клітинами обох типів [4] сприяє зростанню їх активності. Міжклітинна взаємодія $є$ одним із механізмів підтримки клітин фетальної печінки [2]. 3 урахуванням викладеного можна припустити, що взаємодія МСК із ГСК зможе підсилити регенерацію імунної системи на основі більш інтенсивного функціонування і диференціювання в імунні клітини преінкубованих із МСК ГСК і прогеніторів. Це приведе до більш швидкого поновлення імунної системи розвиненими із ГСК імунними клітинами. Останні, реалізуючи свій імунологічний протиінфекційний потенціал, гальмують розвиток кістковомозкового синдрому.

У роботі вивчали вплив на летально опромінених мишей наступних кріоконсервованих препаратів ГСК і прогеніторів: клітин кісткового мозку (ККМ) мишей і клітин фетальної печінки (КФП) мишей, нормальних і попередньо преінкубованих in vitro з сингенними МСК тимуса мишей. Для контролю використовували кондиційне середовище 3 сумісної культури сингенних КФП мишей і МСК тимуса, що культивувалися разом, як клітини основних груп.

Мета роботи - вивчення виживаності летально опромінених мишей після трансплантації ГСК і прогеніторів, преінкубованих із МСК тимуса

\section{Матеріали та методи}

Усі експерименти проводили 3 дотриманням вимог статті 26 Закону України «Про захист тварин віджорстокого поводження» (від 21.02.2006 р.)
Immune deficiency induced by lethal irradiation is most often used to investigate the activity of hematopoietic stem cells and progenitors during regeneration of immune system. The main pathogenetic mechanism of its development is the bone marrow syndrome, occurring as a result of lesion of hematopoietic and lymphoid cells sensitive to ionizing radiation. At the same time, the radiation affects the barrier function of epithelium and socalled intestinal syndrome develops. Immune deficiency is increased by the influence of microbial aggression factors of mucous membranes, resulting in a fatal outcome. Termination of this pathological process is possible only due to the regeneration of immune system with restoration of antiinfective protection.

Nowadays, the use of hematopoietic stem cells (HSCs), forming all the cells of immune system, as well as multipotent stromal cells (MSCs), providing regulatory effect on HSCs is the most effective approach to regenerate an immune system $[8,10]$. Membrane affinity between the cells of both types [9] contributes to the growth of their activity. Cellto-cell interaction is one of the mechanisms supporting fetal liver cells [5]. In view of the foregoing, it can be assumed that an interaction of MSCs with HSCs can enhance the regeneration of immune system on the basis of more intensive functioning and differentiation in immune cells of the MSCspreincubated HSCs and progenitors. This will lead to a faster renewal of immune system by immune cells developed by HSCs. Immune cells implementing their immunological anti-infectious potential, inhibit the development of bone marrow syndrome.

The effect on lethally irradiated mice of cryopreserved products of HSCs and progenitors such as bone marrow cells (BMCs) and fetal liver cells (FLCs) of mice, normal and preincubated in vitro with syngeneic MSCs of murine thymus was studied in the research. Conditioned medium of a combined culture of murine syngeneic FLCs and thymic MSCs, cultured together as the cells of the main groups was used for the control.

The research aim was to study the survival of lethally irradiated mice after transplantation of HSCs and progenitors preincubated with thymic MSCs.

\section{Materials and methods}

All the experiments were conducted in a compliance with the requirements of Article 26 of the Law of Ukraine «On the Protection of Animals Against Cruelty» (dated February 21, 2006) and «European Convention for the Protection of Ver- 
та «Європейської конвенції з захисту хребетних тварин, які використовуються 3 експериментальною та іншою науковою метою» (Страсбург, 1986).

Роботу виконували на 128 самцях мишей лінії CВА масою 18-20 г, які брали у розпліднику віварію Інституту експериментальної патології, онкології і радіобіології ім. Р.Е. Кавецького НАН України (м. Київ). Для отримання КФП використовували 14-денні плоди мишей цієї ж лінії. Тимус і кістковий мозок для отримання МСК i ГСК із прогеніторами одержували від мишей 4-6-тижневого віку.

Для отримання КФП печінку 14-денних ембріонів мишей СВА збирали у флакони 35 мл розчину консерванта (середовище DMEM/F12 («Sigma», США), 2000 од/мл пеніциліну («Дарниця», Україна), 2 мг/мл стрептоміцину («Дарниця»), 2 мг/мл канаміцину («Київмедпрепарат», Україна), 2,5 мкг/мл фунгизону («Briston Myers Squibb», Росія)), промивали та залишали у цьому ж розчині на 2-4 год при $4^{\circ} \mathrm{C}$. Потім консервант видаляли, додавали 2-3 мл розчину Хенкса та руйнували паренхіму печінки за допомогою 3-4-кратного пропускання через наконечник автоматичного дозатора. Переносили одержаний матеріал у пробірку, залишали на 10 хв для осадження крупних фрагментів, після цього однорідну суспензію клітин поміщали в мікропробірки та центрифугували ii 10 хв при $250 \mathrm{~g}$. Осад ресуспендували в середовищі для кріоконсервування (середовище RPMI 1640 («Sigma»), 20\% ембріональної телячої сироватки (ЕTC) («Sigma»), 5\% диметилсульфоксиду (ДМСО) («Sigma»)).

Для одержання ККМ із внутрішнього каналу стегнової кістки мишей за допомогою шприца вимивали кістковий мозок у 2 мл розчину Хенкса, ресуспендували його, пропускаючи послідовно через голки меншого діаметра. Суспензію відстоювали, однорідну суспензію переносили в пробірки та відмивали клітини центрифугуванням (10 хв при $250 \mathrm{~g})$, осад ресуспендували в середовищі для кріоконсервування.

Кріоконсервування проводили згідно 3 методикою В.I. Грищенка та співавт. [3] 3 використанням програмного заморожувача «KRYO-516» («Planer», Велика Британія) у кріопробірках («Nunc», США) об’ємом 1,8 мл. Процес заморожування клітин проводили за 4-етапною програмою (таблиця), після чого кріопробірки переносили до низькотемпературного банку. Клітини зберігали в рідкому азоті протягом 6-7 місяців до початку експерименту.

Розморожування клітин проводили безпосередньо перед застосуванням. Кріопробірки 3 клітинами діставали із рідкого азоту і занурювали tebrate Animals Used for Experimental and Other Scientific Purposes» (Strasbourg, 1986).

The work was performed in 128 male CBA mice of 18-20 g, which were provided by the vivarium nursery of RE Kavetsky Institute of Experimental Pathology, Oncology and Radiobiology of the National Academy of Sciences of Ukraine (Kyiv). To derive FLCs the 14-day-old mice embryos of the same line were used. The thymus and bone marrow to obtain MSCs and HSCs with progenitors were derived from 4-6-week-old mice.

To obtain FLCs, liver of 14-day-old CBA mice embryos was collected in vials containing $5 \mathrm{ml}$ of preservative solution (medium DMEM/F12 (Sigma, USA), $2000 \mathrm{U} / \mathrm{ml}$ Penicillin (PrJSC Darnitsa, Ukraine), $2 \mathrm{mg} / \mathrm{ml}$ Streptomycin PrJSC Darnitsa), $2 \mathrm{mg} / \mathrm{ml}$ Kanamycin (Arterium, Ukraine), $2.5 \mu \mathrm{g} /$ ml Fungicone (Briston Myers Squibb, Russia)), washed and left in the same solution for 2-4 hrs at $4^{\circ} \mathrm{C}$. Then the preservative was removed, 2-3 $\mathrm{ml}$ of Hanks's solution was added and the liver parenchyma was subjected to an injury by 3-4-fold passing through the tip of the automatic dispenser. The obtained material was transferred to the vial, left for $10 \mathrm{~min}$ to sediment large fragments, hereafter a homogeneous suspension of cells was placed in a microtube and centrifuged for $10 \mathrm{~min}$ at $250 \mathrm{~g}$. The sediment was resuspended in cryopreservation medium for (RPMI 1640 medium (Sigma), 20\% fetal bovine serum (FBS) (Sigma), 5\% dimethylsulfoxide (DMSO) (Sigma)).

To obtain BMCs from the inner canal of mice femur the bone marrow was washed using a syringe in $2 \mathrm{ml}$ of Hanks's solution, resuspended, passing gradually through smaller diameter needles. Suspension was sedimented, a homogeneous one

Програма кріоконсервування клітинних препаратів ГСК і прогеніторів

Cryopreservation program of cellular preparations of HSCs and progenitors

\begin{tabular}{|c|c|c|c|c|}
\hline \multirow{2}{*}{$\begin{array}{l}\text { Етап } \\
\text { Stage }\end{array}$} & \multicolumn{2}{|c|}{$\begin{array}{l}\text { Tемпература, }{ }^{\circ} \mathrm{C} \\
\text { Temperature, }{ }^{\circ} \mathrm{C}\end{array}$} & \multirow{2}{*}{$\begin{array}{c}\text { Швидкість } \\
\text { заморожування, } \\
\text { град/хв } \\
\text { Freezing rate, deg/min }\end{array}$} & \multirow{2}{*}{$\begin{array}{l}\text { Час, хв } \\
\text { Time, mir }\end{array}$} \\
\hline & $\begin{array}{l}\text { початкова } \\
\text { Initial }\end{array}$ & $\begin{array}{l}\text { кінцева } \\
\text { Final }\end{array}$ & & \\
\hline 1. & 20,0 & $-4,0$ & $-2,0$ & 8 \\
\hline 2. & $-4,0$ & $-8,0$ & $-0,5$ & 8 \\
\hline 3. & $-8,0$ & $-70,0$ & $-10,0$ & 6,2 \\
\hline 4. & $-70,0$ & $-70,0$ & 0,0 & 5 \\
\hline
\end{tabular}


у водяну баню за температури $40^{\circ} \mathrm{C}$, витримували протягом 30-60 с до появи рідкої фази, потім ще кілька хвилин кріопробірку витримували при кімнатній температурі та після формування однорідної суспензії розморожені клітини відмивали від ДМСО, центрифугуючи 10 хв при $250 \mathrm{~g}$, осад ресуспендували в поживному середовищі (середовище RPMI 1640 з 10\% ETC («Sigma»), 2 мМоль L глутаміну («Sigma»), 10 мМоль HEPES Na-солі («Sigma»), 100 ОД/мл пеніциліну («Дарниця»), 100 мкг/мл стрептоміцину («Дарниця»), 100 мкг/мл канаміцину («Київмедпрепарат», Україна)). Життєздатність клітин оцінювали за допомогою фарбування 0,3\%-м розчином трипанового синього. Вона становила 80-90\%, що відповідає літературним даним [7].

Культуру МСК тимуса мишей отримували на поверхні 6-лункових планшетів із експлантатів фрагментів тимуса. На 12-ту добу культивування, коли утворювалися добре помітні численні колонії фібробластних клітин, із лунок видаляли середовище і додавали $5 \times 10^{6}$ розморожених ККМ або КФП у 2 мл свіжого середовища RPMI 1640 з 10\% ЕТС. Для контролю впливу терміну інкубації клітин та урахування того, що частина клітин може прикріпитися до пластику без контактної міжклітинної взаємодії та змінити свої властивості, ККМ та КФП у тій же кількості та концентрації інкубували в чистих планшетах. Такі клітини використовували для контролю дії ГСК і прогеніторів, інкубованих із МСК тимуса.

Через 20 годин сумісного культивування обережним піпетуванням збирали суспензії ГСК i прогеніторів, які відокремлювалися від МСК тимуса, центрифугували їх протягом 10 хв при $250 \mathrm{~g}$, осад ресуспендували в живильному середовищі RPMI 1640 з 10\% мишачої сироватки до концентрації клітин 2,5 × 106/мл. 3 лунок із сумісною культурою КФП та МСК відбирали культуральне середовище.

Отримані ГСК і прогенітори різних субпопуляцій у кількості 0,5 × $10^{6}$ та в об'ємі 0,2 мл вводили в ретроорбітальний синус опроміненим напередодні (за 24 години) мишам. За даними літератури це мінімальна кількість ККМ, яка може сприяти виживаності летально опромінених мишей [10]. Мишей масою 18-20 г піддавали загальному $\gamma$ опроміненню ${ }^{60} \mathrm{Co}$ у дозі 9 Гр на апараті для дистанційної променевої терапії «ТЕРАТРОН - Elit80» (Канада).

Відповідно до введених клітинних продуктів були сформовані експериментальні групи тварин: 1 - (контрольна група) летально опромінені тварини; 2 - тварини, які отримували кондиційне середовище (КС) від сумісного 20-годинного was transferred to the vials and the cells washed by centrifugation (10 $\mathrm{min}$ at $250 \mathrm{~g})$, the sediment was resuspended in cryopreservation medium.

Cryopreservation was performed according to the method of Grischenko et al. [6] using a programmable freezer KRYO560 16 (Planer, UK) in cryotubes (Nunc, USA) of $1.8 \mathrm{ml}$. The cells were frozen using a 4-stage program (Table), hereafter the cryotubes were transferred to a low-temperature bank. The cells were stored in liquid nitrogen for 6-7 months before the experiment.

The cells were warmed immediately before their use. Cryotubes with the cells were removed from liquid nitrogen and immersed in a water bath at $40^{\circ} \mathrm{C}$, maintained for $30-60 \mathrm{sec}$ before the appearance of liquid phase, then the cryotube was kept at room temperature for a few minutes, and after forming a homogeneous suspension, the frozenthawed cells were washed from DMSO by centrifugation for $10 \mathrm{~min}$ at $250 \mathrm{~g}$. The sediment was resuspended in a nutrient medium (RPMI 1640 with 10\% FBS (Sigma), $2 \mathrm{mM}$ of L-glutamine (Sigma), 10 mM HEPES Na (Sigma), 100 U/ml Penicillin (Darnitsa), $100 \mu \mathrm{g} / \mathrm{ml}$ Streptomycin (Darnitsa), $100 \mu \mathrm{g} / \mathrm{ml}$ Kanamycin (Arterium, Ukraine)). Cell viability was estimated by staining with $0.3 \%$ trypan blue. It made $80-90 \%$, corresponding to published reports [11].

The culture of thymic MSCs of mice was obtained on the surface of 6-well plates from the explants of thymus fragments. On day 12 of culturing, when numerous colonies of fibroblasts were clearly visible, the medium was removed from the wells and supplemented with $5 \times 10^{6}$ of either thawed BMCs or FLCs into $2 \mathrm{ml}$ of fresh medium RPMI 1640 with 10\% FBS. To control the effect of incubation time of cells and to take into account that some of the cells can attach to plastic without contact cell-to-cell interaction and change their properties, BMCs and FLCs in the same amount and concentration were incubated in clean plates. Such cells were used to control the effect of HSCs and progenitors incubated with thymic MSCs.

After $20 \mathrm{hrs}$ of combined culturing, the suspensions of HSCs and progenitors were collected by careful pipetting, separated from the thymic MSCs, centrifuged for $10 \mathrm{~min}$ at $250 \mathrm{~g}$, the sediment was resuspended in RPMI 1640 nutrient medium from $10 \%$ mouse serum to a cell concentration of $2.5 \times$ $10^{6} / \mathrm{ml}$. Culture medium was collected from the wells, containing a combined culture of FLCs and MSCs.

The obtained HSCs and progenitors of various subpopulations in the amount of $0.5 \times 10^{6}$ and $0.2 \mathrm{ml}$ were injected into the retro-orbital sinus of irradia- 
культивування сингенних КФП і МСК; 3 - тварини, які отримували ГСК і прогенітори кісткового мозку, преінкубовані в чистих планшетах (ККМ); 4 - (преінкубовані ККМ) тварини, які отримували ГСК і прогенітори кісткового мозку, преінкубовані з МСК тимуса; 5 - тварини, які отримували ГСК і прогенітори фетальної печінки, преінкубовані в чистих планшетах (КФП); 6 - (преінкубовані КФП) тварини, які отримували ГСК і прогенітори фетальної печінки, преінкубовані з МСК тимуса. За тваринами спостерігали протягом 16 тижнів, фіксуючи дату загибелі кожної миші. Середню тривалість життя тварин визначали за даними динаміки загибелі тварин. Результати представлені у вигляді середніх арифметичних і помилок середніх $(M \pm m)$. Значущість відмінностей між групами оцінювали за допомогою $t$-критерію Стьюдента та точного критерію Фішера. При інтерпретації результатів за критичну величину рівня значущості вважали $p<0,05$.

\section{Результати та обговорення}

Відомо, що популяція ГСК в органах кровотворення $є$ гетерогенною. Найбільшу здатність до самопідтримки і найвищу поліпотентність мають дормантні довго репопулюючі ГСК (ДР-ГСК). Вони характеризуються за SLAM-маркерами як $\mathrm{CD} 150^{+} \mathrm{CD} 49^{-} \mathrm{CD} 41^{-}$-клітини, знаходяться в клітинній фазі G0 та довго зберігають мітку BrdU. Коротко репопулюючі ГСК (КР-ГСК) більш розвинуті на шляху диференціювання. Значну їx частку складають CD34+ LSK-клітини, які перебувають у клітинній фазі G1 [12].

Періоди часу після опромінення і трансплантації ГСК підрозділяють на ранній (2-4 тижні) та пізній $[8,9,11]$. У ранньому періоді відновлення імунної системи здійснюється КР-ГСК, які за функціональним станом готові до швидкого включення у формування більш зрілих клітинпопередників протягом перших 2-4 тижнів після трансплантації. У пізньому періоді до регенерації підключаються ДР-ГСК, які мають високий потенціал до самовідновлення і забезпечують диференціювання та проліферацію лінійних нащадків протягом тривалого часу через 5-6 тижнів після трансплантації [8].

До 14-го тижня усі миші у контрольній групі (летально опромінені тварини) поступово гинули через отримане опромінення (рис. 1). За перший місяць загинуло $70-80 \%$ тварин в усіх групах за виключенням тих, у яких досліджувалися обидва препарати КФП. Введення до КС сумісної культури МСК і КФП не впливало на виживаність тварин.
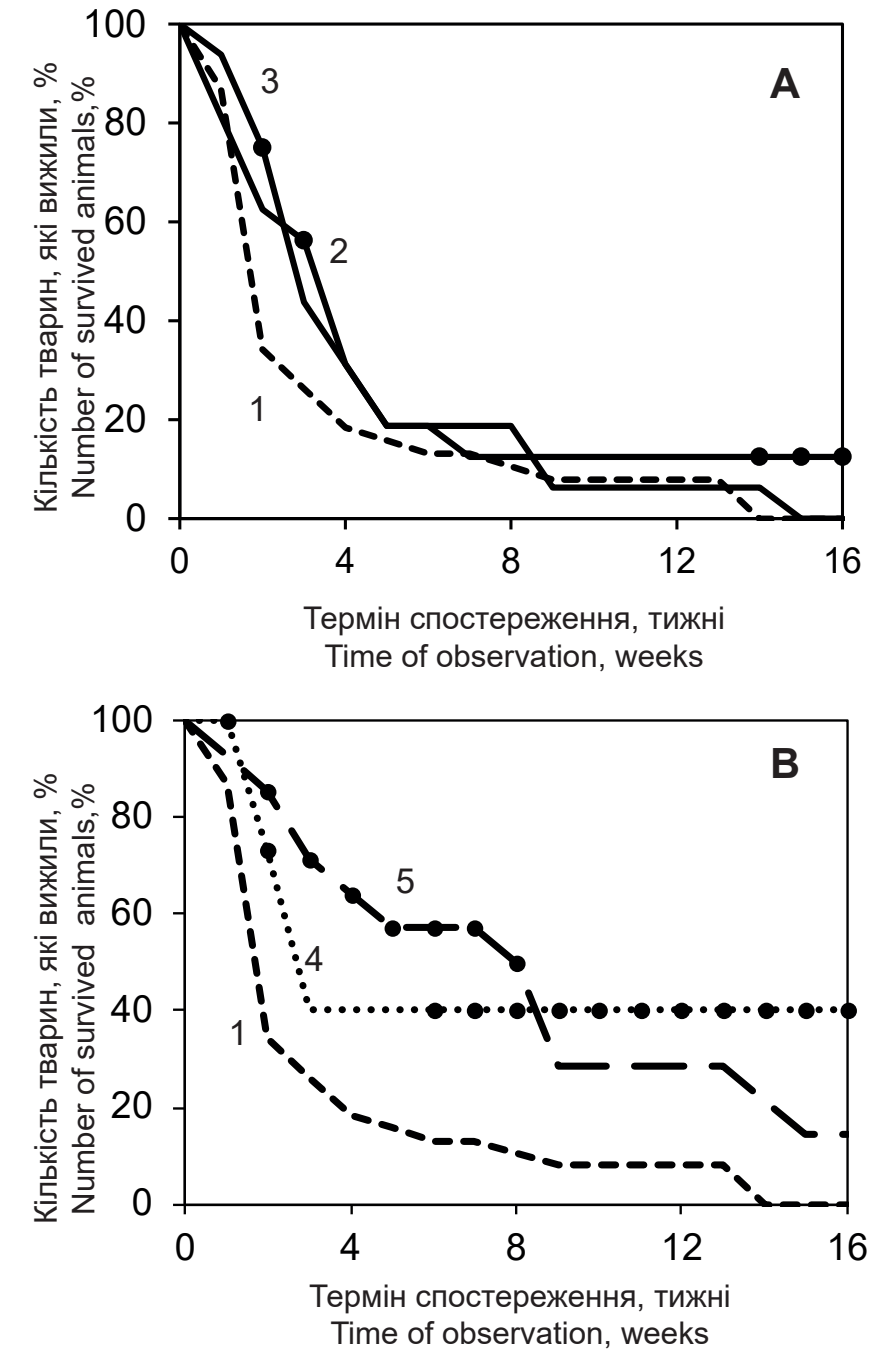

Рис. 1. Динаміка виживаності летально опромінених мишей, захищених нормальними і преінкубованими 3 МСК тимуса ГСК і прогеніторами: A - кістковий мозок, В - фетальна печінка; 1 - опромінені; 2 - ККМ; 3 - ККМ, преінкубовані з МСК тимуса; 4 - КФП; 5 - КФП, преінкубовані з МСК тимуса, $\bullet-p<0,05$ по відношенню до опромінених мишей.

Fig. 1. Survival dynamics of lethally irradiated mice protected by normal and incubated with thymic MSC HSCs and progenitors: A - bone marrow, B - fetal liver. 1 irradiated; 2 - BMCs, 3 - BMCs preincubated with MSCs, 4 - FLCs, 5 - FLCs preincubated with MSCs. $\bullet-p<0.05$ in relation to irradiated mise.

tedmice the day before ( $24 \mathrm{hrs})$. According to the published data, this is the minimum amount of BMCs that can contribute to the survival of lethally irradiated mice [4]. The mice of 18$20 \mathrm{~g}$ were exposed to a total $\gamma$-irradiation of ${ }^{60} \mathrm{C} 0$ at a dose of 9 Gy using a remote-beam therapy apparatus THERRATRON-Elit-80 (Canada).

According to the introduced cell products, the following experimental groups of animals were formed: the $1^{\text {st }}$ one was the lethally irradiated animals (control group); the $2^{\text {nd }}$ one comprised the animals which received the conditioned medium (CM) 
Трансплантація сингенних ККМ мишам призводила до підвищення виживаності на ранніх термінах після опромінення (група 3). На 3-му тижні показник виживаності збільшився в 2,1 рази порівняно 3 контрольними тваринами (група 1). Кількість тварин, які вижили, поступово зменшувалася, а на 15-му тижні загинули всі миші (рис. 1, А).

Позитивний вплив ККМ на початку експерименту, обумовлений наявністю серед ККМ зрілих клітин уродженого імунітету, які здатні до негайної реалізації протиінфекційних імунних реакцій у відповідь на інфекцію із кишківника. Поступово кількість зрілих мієлоїдних клітин уродженого імунітету вичерпувалася, а темпу їх розвитку 3 кістковомозкових КР-ГСК і попередників було недостатньо для відтворення ефективної чисельності. Таким чином можна пояснити і значущу різницю на перших етапах експерименту після введення клітин усіх інших груп, які вивчалися (групи 4-6).

Динаміка виживаності тварин після введення ККМ, преінкубованих із МСК тимуса, на початку експерименту мало відрізнялася від такої у мишей, які отримували нормальні ККМ. Але 3 7-го тижня кількість тварин групи 4 не зменшувалася, показник виходив на плато (13\%) і не змінювався до кінця спостереження. 3 14-16-го тижнів виживаність мишей у групі 4 була суттєво вищою, ніж у контрольній групі. Це свідчить на користь того, що сумісна інкубація МСК і ККМ супроводжується підтримкою життєдіяльності гемопоетичних клітин, скоріш за все, впливом МСК на ДР-ГСК, і підвищенням ефективності їх диференціювання. Таким чином, у більш пізні терміни експерименту зрілі гемопоетичні клітини і лімфоцити формуються за рахунок ДР-ГСК, які завдяки участі у імунологічних реакціях компенсують розвиток летального кістковомозкового синдрому, що і сприяє підвищенню виживаності тварин.

Динаміка виживаності тварин у результаті трансплантації КФП опроміненим мишам значно відрізнялася від тієї, яка спостерігалася у дослідах із ККМ (рис. 1, В). На початку експерименту тварини групи 5 гинули так само швидко, як і контрольні (група 1). Але на 4-й тиждень спостереження виживаність мишей, які отримували нормальні КФП (група 5), виходила на плато (40\%) i не змінювалася до кінця спостереження. По відношенню до контрольної групи на 4-й тиждень виживаність була більшою у 3 рази. Наприкінці експерименту, коли у контрольній групі загибель мишей зростала (на 13-й тиждень залишалося $8 \%$ ), виживаність тварин, які отримували нор- from a combined 20-hour culturing of syngeneic FLCs and MSCs; the $3^{\text {rd }}$ group made the animals, which received HSCs and bone marrow progenitors, preincubated in pure plates (BMCs); the $4^{\text {th }}$ one consisted of the (preincubated BMCs) animals, which received HSCs and bone marrow progenitors preincubated with thymic MSCs; the $5^{\text {th }}$ group was represented by the animals, which received HSCs and progenitors of fetal liver, preincubated in pure plates (FLCs); the $6^{\text {th }}$ group made the (preincubated FLCs) animals, which received HSCs and progenitors of fetal liver preincubated with thymic MSCs. The animals were observed for 16 weeks with fixing the date of death of each mouse.

The average life expectancy of dead animals was determined according to the dynamics of animal death. The results are presented as arithmetic mean and mean errors $(\mathrm{M} \pm \mathrm{m})$. The significance of difference between the groups was estimated using Student's t-criterion and Fischer's exact criterion. When processing the results $p<0.05$ was considered as critical value of significance.

\section{Results and discussion}

The population of HSCs has been known in the organs of hematopoiesis to be heterogeneous. Dormant long-term repopulating HSCs (LTR HSCs) have the strongest ability to self-renewal and the highest polypotency. They are characterized by SLAM-markerslikeCD150 ${ }^{+}$CD $49^{-} \mathrm{CD} 41^{-}$-cells, being in the cell G0 phase and maintain the BrdU marker for a long time. Short-term repopulating HSCs (STR HSCs) are more developed during differentiation. CD34 $4^{+}$-LSK-cells being in the cell G1phase is their significant part [12].

The time periods after irradiation and transplantation of HSCs are subdivided into early (2-4 weeks) and late ones [2, 3, 7]. At early stage an immune system recovered with STR HSCs, which were ready for a rapid involvement into the formation of more mature precursor cells during the first 24 weeks after transplantation. At the late stage, LTR HSCs having a high self-renewal potential and providing the differentiation and proliferation of linear progenies for a long time in 5-6 weeks after transplantation [2] were also involved into regeneration.

To week 14, all the mice of the control group (lethally irradiated animals) were gradually dying as a result of the received radiation (Fig. 1). During the first month, $70-80 \%$ of animals died in all the groups, excluding those with both FLC products. Introduction to CM of a combined culture of MSCs and FLCs did not affect the animal survival. 


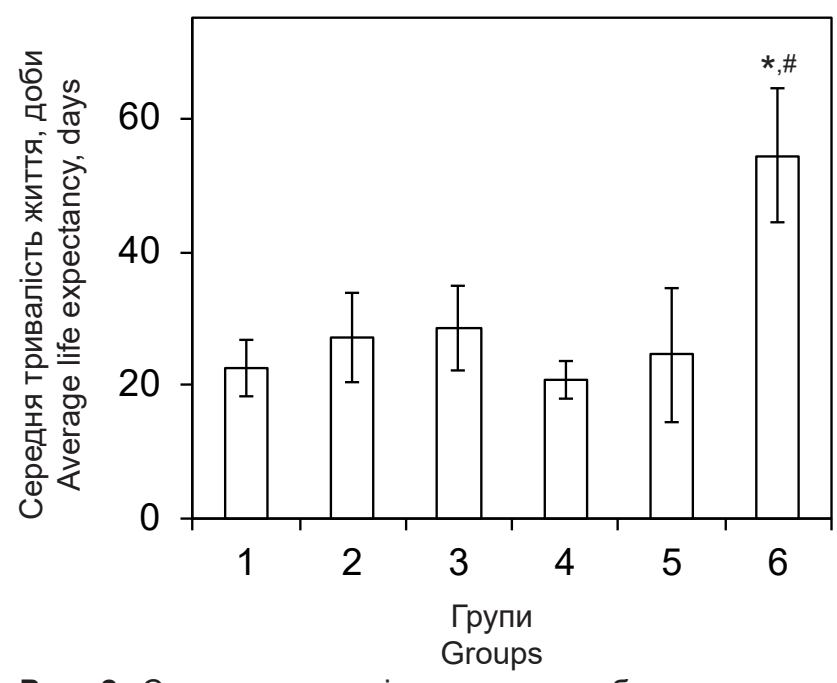

Рис. 2. Середня тривалість життя загиблих летально опромінених мишей, що отримували різні препарати ГСК і прогеніторів. * $-p<0,05$ по відношенню до опромінених мишей, \# - $p<0,05$ між КФП і преінкубованими КФП.

Fig. 2. Average life expectancy of lethally irradiated mice receiving different preparations of HSCs and progenitors. * $-p<0.05$ in relation to irradiated mise, $\#-p<0.05$ between FLCs and preincubated FLCs.

мальні КФП (група 5), перевищувала контрольний рівень у 5,1 раза.

Таким чином, введення нормальних КФП не захищало мишей групи 5 від загибелі на ранньому етапі після опромінення, але призводило до формування ефективних механізмів протирадіаційного захисту, які дозволяють збільшити відсоток виживаності тварин на пізньому етапі.

Підвищення виживаності мишей на різних термінах спостереження, починаючи 3 ранніх, свідчить про наявність у препаратах КФП зрілих мієлоїдних клітин, певної кількості ГСК із прогеніторами [1] i, можливо, КР-ГСК із відповідними відмінностями їх функціонального стану, що сприяє більш швидкому і ефективному диференціюванню клітин імунної системи. Зокрема, відомо, що ГСК фетальної печінки, на відміну від таких клітин кісткового мозку, у більшій кількості знаходяться у фазі G1 клітинного циклу, що свідчить про їх вихід із дормантного стану і більшу готовність до диференціювання. Через більш тривалий час (5-6 тижнів після трансплантації) починають диференціювання і проліферацію ДР-ГСК, що і забезпечує ефективніше відновлення імунної системи і збереження тварин на пізньому після опромінення етапі.

Виживаність летально опромінених мишей після трансплантації КФП, преінкубованих із МСК (група 6), була суттєво вищою у перші тижні, на 8-му тижні досягала максимальної різниці (у 4,8 раза) порівняно з опроміненими тваринами
Transplantation of syngeneic BMCs to mice resulted in an increased survival at the early stage after irradiation (group 3). To week 3, the survival rate was increased by 2.1 times if compared with the control animals (group 1). The number of survived animals gradually decreased, and at week 15 all the mice died (Fig. 1, A).

The positive effect of BMCs at the beginning of experiment is stipulated with the presence of innate immunity mature cells in BMCs, capable of immediate implementation of anti-infective immune responses to intestinal infection. Gradually, the number of mature myeloid cells of innate immunity was decreased, and their development rate from bone marrow STR HSCs and precursors was insufficient to reproduce their effective population. Thus, it is possible to explain a significant difference at the first stages of experiment after introduction of the cells of all other studied groups (groups 4-6).

The dynamics of animal survival after introduction of BMCs preincubated with thymic MSCs, at the beginning of experiment was slightly different from that in mice which received normal BMCs. But from week 7, the number of animals in group 4 did not decrease, the index was 13\% and did not change until the end of the observation. From weeks 14-16 the survival rate of mice in group 4 was significantly higher than in the control group. This suggests that a combined incubation of MSCs and BMCs is accompanied by the support of hematopoietic cells activity, most likely by the influence of MSCs on LTR HSCs, and by increasing the efficiency of their differentiation. Thus, at late stages of the experiment, mature hemopoietic cells and lymphocytes are formed due to LTR HSCs, which, by means of participation in immunological reactions, compensate the development of lethal bone marrow syndrome, contributing to an increase in the animals' survival.

The survival rate of animals as a result of FLC transplantation to irradiated mice was significantly different from that observed in the BMCs (Fig. 1, B). At the beginning of the experiment, the animals of group 5 died as fast as the control one (group 1). But on week 4 of observation, the survival of mice received normal FLCs (group 5) was $40 \%$ and did not change until the end of observation. As for the control group to week 4, the survival rate was 3 times higher. At the end of experiment, when the death of mice in the control group increased (8\% remained to week 13), the survival rate of the animals which received normal FLCs (group 5) exceeded the control level by 5.1 times.

Thus, the administration of normal FLCs did not protect the mice of group 5 against dying at an 
(група 1). Наприкінці дослідження у мишей групи 6 була тенденція до зниження виживаності порівняно з групою 5, але між цими двома групами значущої різниці у виживаності не спостерігалося. Можна припустити, що позитивний ефект на початку експерименту пов'язаний зі стимуляцією МСК реакцій уродженого імунітету і активацією КР-ГСК фетальної печінки. Однак у пізній після опромінення період контактуючі МСК тимуса стимулюють ДР-ГСК, які виконують основну функцію у регенерації імунної системи.

Для аналізу активності клітин в експерименті визначали середню тривалість життя (СТЖ) загиблих тварин (рис. 2), на яку нормальні ККМ, преінкубовані ККМ та нормальні КФП суттєво не впливали. Однак преінкубовані КФП підвищували цей показник порівняно з групою 1 у 2,4 рази саме за рахунок кращої виживаності тварин на ранньому етапі експерименту.

Таким чином, встановлено, що преінкубовані ККМ, на відміну від нормальних ККМ, збільшували виживаність летально опромінених мишей на пізньому після опромінення етапі, що, ймовірно, відбувається за рахунок підвищення функціональної активності ДР-ГСК внаслідок їх інкубаціï з МСК тимуса. Преінкубовані з МСК тимуса сингенні КФП значно підвищували виживаність на ранньому після опромінення етапі, вірогідно, за рахунок стимуляції КР-ГСК. На пізньому етапі зберігалася приблизно така ж кількість мишей, як і в групі тварин, які отримували нормальні КФП (група 5), ймовірно за рахунок підвищення активність ДР-ГСК. У результаті цього показник СТЖ загиблих мишей значно підвищувався у групі тварин, які одержували преінкубовані з МСК тимуса сингенні КФП, які ефективніше впливали на виживаність мишей на ранньому та пізньому після опромінення етапах.

Отримані дані щодо суттєвого позитивного впливу кріоконсервованих і преінкубованих iз МСК тимуса ГСК підкреслюють важливість знань про взаємодію гемопоетичних і стромальних клітин в імунній системі і у подальшому можуть бути використані для розробки нових підходів до підвищення ефективності трансплантації ГСК у клінічній практиці.

\section{Висновки}

1. Трансплантація опроміненим мишам інтактних ККМ приводить до підвищення виживаності тільки у ранні терміни експерименту. Індуковані ККМ суттєво підвищують виживаність як на початку, так і наприкінці досліду, що свідчить про зростання активності ККМ у результаті контактної взаємодії з МСК тимуса. early stage after irradiation, but led to the formation of effective anti-radiation protection mechanisms, allowing an increased percentage of animal survival at the late stage.

Rise in the survival rate of mice at different observation stages, from the earliest, testifies to the presence of mature myeloid cells in FLC preparations, a certain amount of HSCs with progenitors [1], and likely STR HSCs with the corresponding differences in their functional state, contributing more rapid and effective differentiation of cells of immune system. It is known that fetal liver HSCs, in contrast to those of bone marrow cells, are more represented in the G1 phase of cell cycle, indicating that they are out of the dormancy and are more ready for differentiation. In a longer time (56 weeks after transplantation), LTR HSCs begin differentiation and proliferation, providing more effective recovery of immune system and animal survival at the late stage after irradiation.

The survival of lethally irradiated mice after transplantation of FLCs preincubated with MSCs (group 6) was significantly higher in the first weeks, at the $8^{\text {th }}$ week, there was achieved the maximum difference (4.8 times) if compared to the irradiated animals (group 1). At the end of the study in group 6 , there was a tendency to a decreased survival if compared to group 5, but no significant difference in survival was observed between these two groups. We can assume that the positive effect at the beginning of experiment was associated with stimulation of MSC reactions of innate immunity and activation of fetal liver STR HSCs. However, at the late stage after irradiation contacting thymic MSCs stimulate LTR HSCs, having an active role in regeneration of immune system.

When analysing cell activity in the experiment, the mean life expectancy (MLE) of dead animals (Fig. 2) was determined, on which normal BMCs, preincubated BMCs and normal FLCs did not significantly affect. However, preincubated FLCs increased this index if compared to the group 1 by 2.4 times due to higher animal survival at the early stage of the experiment.

Thus, it has been established that preincubated $\mathrm{BMCs}$, in contrast to normal BMCs, increased the survival rate of lethally irradiated mice at the late stage of irradiation, that is probably due to enhanced functional activity of LTR HSCs after their incubation with thymic MSCs. Preincubated with thymic MSCs syngeneic FLCs significantly increased the survival at an early post-irradiation stage, probably due to the stimulation of STR HSCs, while retaining approximately the same number of mice at the late stage as in the group of animals received 
2. Інтактні КФП також підвищують виживаність у ранні терміни та у більш пізньому періоді, коли показник виживаності мишей виходить на плато і зберігається на високому рівні до закінчення експерименту, що свідчить про виражену активність КФП. У результаті трансплантації преінкубованих КФП значно підвищується виживаність тварин у першій частині експерименту, а у другій - він зрівнюється 3 тим, який забезпечують нормальні КФП. Зазначена динаміка виживаності узгоджується зі значним підвищенням у групі реципієнтів преінкубованих КФП середньої тривалості життя загиблих тварин, що теж у цілому свідчить про виражену стимуляцію регенерації імунної системи опромінених мишей КФП у результаті їх контактної взаємодії з МСК тимуса.

Автор висловлює подяку кандидату медичних наук, провідному науковому співробітникові Л.І. Таранусі, кандидату медичних наук, старшому науковому співробітнику О.Г.Федорчуку та молодшому науковому співробітникові Я.-М. А. Семеновій за технічну допомогу під час виконання роботи.

\section{Література}

1. Базыка ДА, Беляева НB, Бебешко ВГ. CD34+-предшественники в криоконсервированной ткани эмбриональной печени человека. Український журнал гематології та трансфузіології. 2001; 3(1): 30-5.

2. Гольцев АН, Рассоха ИВ, Луценко ЕД, и др. Межклеточные взаимодействия в иммунокомпетентной сфере при ревматоидном артрите после применения гемопоэтических клеток эмбриональной печени. Проблемы криобиологии. 2003 (3): 45-53.

3. Грищенко ВИ, Лобынцева ГС, Вотякова ИА, Шерешков СИ. Гемопоэтические клетки эмбриональной печени. Киев: Наукова думка; 1988. 192 с.

4. Никольская ЕИ. Мембранное взаимодействие еx vivo мультипотентных стромальных и гемопоэтических клеток. Імунологія та алергологія. 2011; (4): 100-1.

5. Никольская ЕИ, Бутенко ГМ. Структурно-фуункциональная организация костномозговых ниш гемопоэтических стволовых клеток. Клітинна та органна трансплантологія. 2016; 4(1): 82-100.

6. Нікольський IC, Нікольська ВВ, Демченко ДЛ, та ін. Вплив трансплантації мультипотентних стромальних клітин тимуса на імунну систему мишей в умовах ії регенерації. Фізіологічний журнал. 2018; 64(4): 3-11.

7. Тарасов АИ, Петренко АЮ, Грищенко ВИ, Джонс ДРЕ. Жизнеспособность клеток эмбриональной печени человека различного фенотипа после криоконсервирования. Проблемы криобиологии. 2002; (3): 36-41.

8. Chen J, Astle CM, Harrison DE. Characterization of a hematopoietic stem cell with engraftment advantage. Exp Hematol. 2000; 28(12): 1498.

9. Coulombel L. Identification of hematopoietic stem/progenitor cells: strength and drawbacks of functional assays. Oncogene. 2004; 23(43): 7210-22. normal FLCs (group 5), increasing, most likely, the activity of LTR HSCs. As a result, the MLE index of dead mice was significantly increased in the group of animals which received syngeneic FLCs preincubated with thymic MSCs that had more pronounced effect on the survival of mice at the early and post-irradiation stages.

The obtained data on a significant positive effect of cryopreserved and preincubated with thymic MSCs HSCs emphasized the importance of knowledge about the interaction of hematopoietic and stromal cells in immune system and in future can be used to develop new approaches to enhance the efficiency of HSC transplantation in clinical practice.

\section{Conclusions}

1. Transplantation of intact BMCs to irradiated mice led to an increased survival only at the early stages of experiment. Induced BMCs significantly increased the survival at the beginning and at the end of experiment, testifying to a rise in BMC activity as a result of a contact interaction with thymic MSCs.

2. Intact FLCs also increased the survival rate of mice at the early stage, and at the late one when it remained high until the end of experiment, indicating a pronounced FLC activity. As a result of transplantation of preincubated FLCs, animal survival in the first half of the experiment was significantly increased, and in the second part of experiment, it was equal to that provided by normal FLCs. The indicated survival rate was consistent with a significant rise in life expectancy of animals in the group with preincubated FLCs that supported a pronounced stimulation with FLCs of regeneration of immune system of irradiated mice as a result of their contact interaction with thymic MSCs.

The author is grateful to the candidate of medical sciences, leading researcher L.I. Taranusi, candidate of medical sciences, senior researcher O.G. Fedorchuk and junior researcher Ya.-M.A. Semenova for technical assistance during the research.

\section{References}

1. Bazyka DA, Belyaeva NV, Bebeshko V.G. [CD34+ precursors in the cryopreserved tissue of the human embryonic liver]. Ukrainian Journal of Hematology and Transfusiology. 2001; 3(1): 30-5. Russian.

2. Chen J, Astle CM, Harrison DE. Characterization of a hematopoietic stem cell with engraftment advantage. Exp Hematol. 2000; 28(12), 1498. 
10.Ghosh S, Indracanti N, Joshi J, Indraganti PK. Rescuing Self: Transient Isolation and Autologous Transplantation of Bone Marrow Mitigates Radiation-Induced Hematopoietic Syndrome and Mortality in Mice. Front Immunol [Internet]. 2017; [Cited 2018 Nov 25]; 8: 1180. Available from: https://www.frontiersin. org/articles/10.3389/fimmu.2017.01180/full.

11. Knaän-Shanzer S, Verlinden SF, van Beusechem VW, et al Intrinsic potential of phenotypically defined human hemopoietic stem cells to self-renew in short-term in vitro cultures. Exp Hematol. 1999; 27(9): 1440-50.

12.Weksberg DC, Chambers SM, Boles NC, Goodell MA. CD150side population cells represent a functionally distinct population of long-term hematopoietic stem cells. Blood. 2008; 111(4): 2444-51
3. Coulombel L. Identification of hematopoietic stem/progenitor cells: strength and drawbacks of functional assays. Oncogene. 2004; 23(43): 7210-22.

4. Ghosh S, Indracanti N, Joshi J, Indraganti PK. Rescuing Self: Transient Isolation and Autologous Transplantation of Bone Marrow Mitigates Radiation-Induced Hematopoietic Syndrome and Mortality in Mice. Front Immunol [Internet]. 2017 Sep 25 [cited 2018 Nov 25];8:1180. Available from: https:// www.frontiersin.org/articles/10.3389/fimmu.2017.01180/full.

5. Goltsev AN, Rassokha IV, Lutsenko ED, et al. Intercellular interactions in immunocompetent sphere at rheumatoid arthritis following the application of hematopoietic embryonic liver cells. Problems of Cryobiology. 2003; (3): 45-53.

6. Grischenko VI, Lobyntseva GS, Votyakova IA, Shereshkov SI. [Hematopoietic cells of the embryonic liver]. Kyiv: Naukova dumka. 1988; 192. Russian.

7. Knaän-Shanzer S, Verlinden SF, van Beusechem VW, et al Intrinsic potential of phenotypically defined human hemopoietic stem cells to self-renew in short-term in vitro cultures. Exp Hematol. 1999; 27(9): 1440-50.

8. Nikolskaya EI, Butenko GM. Structural-functional organisation of the bone marrow hematopoietic stem cells niches. Cell and Organ Transplantology. 2016; 4(1):100-17.

9. Nikolskaya El. [Membrane interaction ex vivo multipotent stromal and hematopoietic cells]. Imunologiya ta alergologiya. 2011; (4): 100-1. Russian.

10.Nikolsky IS, Nikolskaya VV, Demchenko DL, et al. [Effects of multipotent stromal cell transplantation on mice immune system under conditions of its regeneration]. Fiziol Zh. 2018; 64(4): 3-11. Ukrainian.

11. Tarasov AI, Petrenko AYu, Grischenko VI, Jones DRE. Postthaw viability of human fetal liver cells of different phenotype. Problems of Cryobiology. 2002; (3): 36-41.

12.Weksberg DC, Chambers SM, Boles NC, Goodell MA. CD150side population cells represent a functionally distinct population of long-term hematopoietic stem cells. Blood. 2008; 111(4): 2444-51. 